\title{
Complete feed block as a mode of enhancing ruminant production: A review
}

\author{
S. Haloi ${ }^{1 *}$, R. Bhuyan ${ }^{1}$, L. Borah $^{1}$ and B. N. Saikia ${ }^{1}$ \\ ${ }^{1}$ Department of Animal Nutrition, College of Veterinary Science, Assam Agricultural University, \\ Khanapara, Guwahati- 781 022, Assam, India
}

\begin{abstract}
Livestock farming is an important source of livelihood in developing countries including India. The production of livestock feeds and fodders is reducing due to the growing human population. Due to a shortage of good quality feeds and fodders, ruminants are mostly fed on crop residues that do not fulfill nutrient requirements for higher production. Complete feed block is a practical useful technology to provide balanced nutrition and to obtain optimum production from ruminant animals. This is one of the greatest ways of improving the utilization of locally available feed ingredients. In addition to this, agro-industrial by-products and non-conventional feedstuffs can be incorporated in complete feed block to minimise feeding and transportation cost, and maximise production. In this feeding method, animals are unable to make choices due to uniform mixing of feed ingredients which results in uniform load on the rumen and thus reduces fluctuation in the release of ammonia for more efficient utilization of non-protein nitrogen. Feeding of complete feed block is a noble way to increase the voluntary feed intake in ruminants. It also improves nutrient utilization by stabilizing rumen fermentation. Besides having many advantages like cheaper storage cost, easy transportation and handling, it is also helpful to provide nutrient requirements during the season of fodder scarcity.
\end{abstract}

Key words: Complete feed block, Growth performance, Milk yield, Nutrient intake, Nutrient utilization

\section{Introduction}

The livestock sector is a survival enterprise for a major part of the Indian as well as world population. Nutritional security, income generation and employment are some important aspects related to the livestock industry. In a country like India, about $70 \%$ of farmers are of marginal and landless category and income from milk makes a significant contribution in sustaining their livelihood. Due to human population pressure, feed and fodder availability has become the major constraint in the development of the livestock industry (Beigh et al., 2017). Proper nutrition and management are crucial to obtain maximum productivity in dairy cows (Dixit et al., 2020). In developing countries like India, ruminant animals are primarily maintained on crop residues which are not optimum for maintaining good health and production. To obtain maximum production, there is a need for easily available feed that fulfills the nutrient requirements of animals. In such cases, complete feed block (CFB) helps in providing a balanced ration to the animals, thereby improving productive performance and income generation. CFB has several benefits like cheaper storage, easy transportation, handling and meet multi-nutritional deficiency. CFB is recommended by several workers (Yadav et al., 1990; Raghuvansi et al., 2002; Vaithiyanathan et al., 2004) to improve rumen microbial efficiency. This practice stabilizes rumen fermentation, reduces fermentation loss, and thereby ensures better utilization of ammonia (Prasad et al., 2001). Densified CFB can also be used as a carrier of prophylactic medicines. Different supplements, feed additives, anthelmintics, neutraceuticals can be added to CFB for enhancing nutritional quality. It is an efficient technology to utilize low-cost crop residues and by-products that reduce the requirement of conventional feed and ultimately reduces the feed cost. Preparation of

*Corresponding Author 
CFB aids in the conservation of seasonally available crop residues to make them available during the scarcity period. Moreover, it provides great relief in feeding livestock during natural calamities due to its compactness and long shelf life.

\section{Processing and use of complete feed block}

The process of making CFB includes grinding of concentrates followed by mixing and addition of feed additives. Again, this is followed by uniform mixing of the ingredients and roughages in proper proportion with molasses and suitable binders in a mechanical mixer or manually. Finally, the weighed quantity of mixed material is transferred to the feed block machine to make CFB.

CFB should be introduced gradually as the gradual increase in amount helps animals in adapting the feed. This is important when animals went through a degree of underfeeding as intake can be faster than normal. Control of feeding time is the best way to restrict intake during the adaptation period. Feed blocks containing urea should not be given to monogastric animals or to pre ruminant calves and young kids and lambs below three months of age as they are not able to use ammonia generated from urea efficiently, thus leads to intoxication.

\section{Importance of complete feed block during lean seasons}

The shortage of feeds and fodders has been a persistent problem affecting the livestock industry (Karangiya et al., 2016). Moreover, harsh weather conditions and natural calamities also reduce the availability of feeds. In such situations, easily available feeds are needed that furnishes the nutrient requirements of the animals cost-effectively. CFB can be helpful during feed scarcity to maintain body weight in animals (Chaturvedi et al., 2014). Densified $\mathrm{CFB}$ is a great way of improving the nutritive value of poor-quality roughages (Salem and Nefzaoui, 2003). Moreover, CFB is compact, needs very little storage so can be easily transported from one place to another which makes it an important feed source during the time of scarcity and natural calamities.

\section{Effects of feeding complete feed block on different performance parameters}

Nutrient intake: The physical form of diet affects the consumption rate in animals, which generally increases with densification. Various studies have shown enhancement in nutrient intakes of animals fed CFB. Improved dry matter (DM) intake was observed by Raghuvansi et al. (2007) in lambs fed CFB compared to those maintained on grazing with supplementation of concentrates. They concluded that the physical nature of the feed, as well as the post-ingestion phenomenon, was accountable for higher DM intake. Munasik et al. (2015) observed higher OM (organic matter) intake in cows fed CFB in the form of cube, cylinder and ball compared to separate feeding of roughages and concentrates indicating the efficient utilization of feed in CFB fed cows. Feeding of CFB improved DM intake in calves (Das et al., 2004a) and crude protein (CP) intake in crossbred cows compared to separate feeding of roughages and concentrates (Haloi et al., 2020). Likewise, Sarker et al. (2019) reported that total mixed ration (TMR) as block and mash form improved the DM and CP intakes in red Chittagong cows compared to feeding of roughages and concentrates separately in a conventional manner. The higher nutrient intakes were might be the consequences of higher nutrient density of the rations. Verma $e t$ al. (1996) also noticed higher DM and digestible DM intake in buffaloes on block form compared to the mash form of diet. They stated that higher bulk density in CFB (3.90 times greater than its mash form) resulted in a higher intake of DM. Singh et al. (2007) observed 30\% higher DM intake in crossbred calves fed CFB than those fed on mash feed as the calves on CFB were unable to make selection which led them to eat more. Conversely, some of the workers did not observe an alteration in DM intake on feeding CFB (Samanta et al., 2003; 
Afzal et al., 2009; Singh et al., 2016) which may be due to a similar plane of nutrition among different experimental groups.

Nutrient utilization: Feeding of CFB is advantageous in utilizing low-grade roughages (Afzal et al., 2009; Saijpaul et al., 2016; Singh et al., 2016). It gives scope for using cheap ingredients and locally available by-products for economic livestock feeding. CFB feeding improves nutrient utilization as a complete diet stabilizes ruminal fermentation (Lailer et al., 2005). Raghuvansi et al. (2007) noticed improved $\mathrm{OM}, \mathrm{CP}$ and energy digestibility in lambs maintained on CFB diet than those on grazing with concentrates supplementation. They did not find significant differences in DM digestibility between the two groups. Improved digestibility coefficient of various nutrients viz. DM, CP, EE (ether extract) and NDF (neutral detergent fibre) were observed by Sarker et al. (2019) in cows fed TMR as block and mash in comparison to cows on separate feeding of roughages and concentrates, while the digestibility coefficient of ADF (acid detergent fibre) did not change among the groups. In contrary to this report, Lailer et al. (2010) did not notice statistical significance in terms of DM, EE and CF (crude fibre) digestibility among buffaloes on CFB and conventional diet (separate feeding of roughages and concentrates). Karimizadeh et al. (2017) noticed better digestibility of DM, CP, NDF and $\mathrm{ADF}$ in lambs fed CFB than mash and pelleted diet. They observed the rumen protozoa population (RPP) among the experimental groups and associated the higher nutrient digestibility with higher (RPP) in the CFB diet. The whole Entodinimus spp., Diplodinium spp. and Epidinium spp. were higher on the CFB diet than the other diets. About 16 to $30 \%$ of total rumen microbial fibre digestion is accomplished by protozoa (Lee et al., 2000; Jabari et al., 2014). According to Jabari et al. (2014), these species have a high ability to degrade cellulose and hemicellulose. Samanta et al. (2003) did not observe significant differences in the digestibility coefficient of $\mathrm{DM}, \mathrm{OM}, \mathrm{CP}, \mathrm{CF}$ and NFE in mash fed or CFB fed Barbari goats. Similar results were obtained from Verma et al. (1996) in Murrah buffaloes and Singh et al. (1998) in buffalo calves.

Growth performance: The CFB is an innovation to ensure balanced nutrient supply and optimal production in domestic animals. Various studies have observed the advantages of feeding CFB on the growth performance of animals. Chaturvedi et al. (2014) concluded that supplementation of complete feed in block form to grazing ewes during scarcity period in the semi-arid region was helpful in sustaining their body weight (BW) due to the better nutrient availability than unsupplemented ewes maintained on sole grazing. Unlikely, Sharma et al. (2010) did not find a significant difference in average daily body weight gain $(509,556$ and $496 \mathrm{~g}$ /day) of crossbred calves fed either wheat straw ad libitum and concentrate mixture separately in conventional form or the wheat straw-based complete feed in mash and block form. The similar nutrient digestibility might have resulted in similar average daily body weight gain among the groups. Nagalakhsmi and Reddy (2011) reported that feeding complete feed in block form led to higher average daily body weight gain and nitrogen retention compared to complete mash feed in lambs. Karimizadeh et al. (2017) also observed higher average body weight gain in lambs receiving CFB than mash and pelleted diet. The higher body weight was probably due to the higher nutrient digestibility in CFB fed lambs. Furthermore, higher BW gain was recorded by Singh et al. (2007) in crossbred calves fed CFB in comparison to mash form of the same complete feed. Ghosh and Chatterjee (2011) inferred that feeding of Maize stover-based complete feed in block form compared to straw and tree leaves-based diet supplemented with concentrate mixture in conventional form did not have an adverse effect on BW change in yaks during winter. Similarly, Singh et al. (2016) did not observe a significant difference 
in average daily body weight gain between crossbred calves fed on wheat and rice strawbased complete feed either as CFB or mash diet. The similar nutrient digestibility might be the reason for similar average daily body weight gain among the groups.

Blood profile: Several workers have noticed that feeding of CFB did not have adverse effects on blood profile. Plasma urea nitrogen generally indicates dietary CP intake. It also indicates the ratio of dietary $\mathrm{CP}$ to ruminally fermentable $\mathrm{OM}$ and ruminal protein supply. Feeding of complete feed in block form increased the concentration of blood urea nitrogen (BUN) compared to mash and pelleted form in lambs but did not affect the concentration of glucose (Karimizadeh et al., 2017). Higher BUN may be related to more CP intake from the CFB diet. Samanta et al. (2003) reported that change in concentration of blood glucose, plasma urea nitrogen and total protein was not significant when the complete diet was given as block and as such in Barbari goats. Sharma et al. (2010) observed similar serum glucose, total protein, albumin and globulin concentrations when calves were fed with roughages and concentrates separately or complete feed as block or mash diet. Singh et al. (2016) fed CFB and conventional diet (separate feeding of roughages and concentrates) to crossbred calves but did not observe a significant difference in glucose, total protein, albumin and globulin concentration in serum.

Milk yield and composition: Uniform mixing of roughage and concentrate and its densification increase energy density of ration thus improve performance in dairy animals (Reddy et al., 2003). Medhi et al. (2016) reported that feeding of complete feed in block form improved the lactation performance of yaks compared to those on free grazing during winter. Wanapat et al. (1999) also observed that feeding of high-quality feed block (HQFB) improved milk yield in comparison to separate feeding of roughages and concentrates in lactating dairy cows since it furnished the additional and essential nutrients required for milk production on a continuous basis.
Likewise, during an on-farm trial, Das et al. (2004b) also observed higher average milk yield in CFB fed lactating buffaloes than those on mash feeding. Contrary to this report, Samanta et al. (2008) found that feeding wheat straw and grass-based densified blocks to lactating crossbred cows had no significant effect on milk yield compared to those fed the mash diet. Similarly, Munasik et al. (2015) found no significant difference in milk production of dairy cattle fed CFB, and roughages and concentrates separately in a conventional way. This was presumably due to the similar DM digestibility in all diets.

Feeding of CFB diets to dairy animals has different effects on milk composition. Haloi et al. (2020) reported higher milk fat percentages in crossbred cows fed CFB and TMR compared to those fed with roughages and concentrate separately, with no effect on milk total solids (TS), solid-not-fat (SNF) and milk protein content. They concluded that higher fat percentages might be related to higher NDF intake in CFB and TMR diets. Lailer et al. (2010) stated that feeding wheat straw and bajra straw-based CFB has a similar effect on milk yield and milk constituents (Fat, SNF and TS). Similarly, Haloi et al. (2021) reported that feeding of CFB did not affect $\mathrm{pH}$, titratable acidity (\%) and specific gravity of milk in crossbred cows. As per the report of Sarker et al. (2019), feeding of TMR in block or mash form was beneficial for milk production over feeding roughages and concentrates separately in red Chittagong cows. They associated the improved milk yield with higher CP intake in cows fed mash and block form of TMR. They also reported increased fat and SNF percentages of milk on TMR feeding as mash and block in comparison to separate feeding of roughages and concentrates. However, protein and lactose content was not affected.

Complete feed block has great importance in ruminant feeding for providing balanced nutrition and reducing feed wastage, but its use is still restricted to the organized farms. As various types of costly machinery are needed 
for preparing $\mathrm{CFB}$, this technology is not economically viable for small and marginal livestock farmers. To extend this technology to the field, attempts should be made in providing small-scale machinery for disintegrating forage, blending ingredients and making feed blocks for the farmers. Thus to make this technology useful for farmers more efforts are needed.

\section{Conclusion}

The CFB plays an important role in supplying balanced rations to ruminants for sustainable livestock farming. Apart from

\section{REFERENCES}

Afzal Y, Ganai AM, Matoo FA and Shad FI, 2009. Comparative evaluation of oats and tree leavesbased complete feed blocks and mash form in sheep. Indian J Small Ruminants, 15(2): 212-216

Beigh YA, Ganai AM and Ahmad HA, 2017. Prospects of complete feed system in ruminant feeding: A review. Vet world, 10(4): 424-437, doi: 10.14202/vetworld.2017.424-437

Chaturvedi OH, Bhatt RS and Sahoo A, 2014. Nutrient utilisation in grazing ewes supplemented with complete feed blocks during scarcity in semi-arid region. Indian J Small Ruminants, 20(1): 114-117

Das MM, Samanta AK, Singh KK, Kundu SS, Sharma SD et al., 2004a. Effect of form of complete diets on nutrient utilization in crossbred calves. Indian J Anim Sci, 74(9): 969-972

Das MM, Singh KK, Samanta AK, Kundu SS and Sharma SD, 2004b. Effect of complete feed blocks on milk yield and its composition in buffalo. In: Proceedings of XI Animal Nutrition Conference, Jabalpur, Jan 5-7, pp 78

Dixit CP, Bhuyan D, Bhuyan M, Ahmed K, Haloi S et al., 2020. Prevalence of various reproductive disorders in the foothills of Himalaya. J Anim Res, 10(4): 635-640, doi: 10.30954/2277940X.04.2020.24

Ghosh MK and Chatterjee A, 2011. Nutrient digestibility and live weight change in yaks fed maize stover based complete feed block during winter. Indian J Anim Sci, 81(4): 427-428

Haloi S, Borah L, Bhuyan R, Saikia BN, Requib M et al., 2020. Lactational performance of crossbred dairy cows fed on complete feed block and total mixed ration. J Entomol Zool Stud, 8(4): 11841187 augmenting the production potential of animals, it also reduces feed wastage and selective feeding, and thus reduces the feed cost. So, CFB feeding in ruminants is more preferable to conventional feeding of roughages and concentrates separately and it can be practically adopted by farmers for feeding ruminant livestock on large scale. Though, lots of efforts are still required to extend this technology to the field.

Conflict of interest: Authors have no conflict of interest in this study.

Haloi S, Borah L, Bhuyan R, Saikia BN, Requib M et al., 2021. Effect of feeding complete feed block and total mixed ration on milk quality in crossbred lactating cows. Pharma Innovation, 10(4): 356-357

Jabari S, Eslam M, Chaji M, Mohammadabadi T and Bojarpour M, 2014. Comparison digestibility and protozoa population of Khuzestan water buffalo and Holstein cow. Vet Res Forum, 5(4): 295-300

Karangiya VK, Savsani HH and Ribadiya NK, 2016. Use of densified complete feed blocks as ruminant feed for sustainable livestock production: A review. Agri Rev, 37(2): 141-147

Karimizadeh E, Chaji M and Mohammadabadi T, 2017. Effects of physical form of diet on nutrient digestibility, rumen fermentation, rumination, growth performance and protozoa population of finishing lambs. Anim Nutr, 3(2): 139-144, doi: 10.1016/j.aninu.2017.01.004

Lailer PC, Dahiya SS and Chauhan TR, 2005. Complete feed for livestock concept, present status and future trend: A review. Indian J Anim Sci, 75(1): 84-91

Lailer PC, Dahiya SS, Lal D and Chauhan TR, 2010. Effect of complete feed blocks on the performance of lactating buffaloes. Indian J Anim Nutr, 27(2): 147-151

Lee SS, Ha JK and Cheng KJ, 2000. Relative contributions of bacteria, protozoa, and fungi to in vitro degradation of orchard grass cell walls and their interactions. Appl Environ Microbiol, 66(9): 3807-3813, doi: 10.1128/ AEM.66.9.3807-3813.2000

Medhi D, Hanah SS, Sarmah PP, Tsering K, Ali E et al., 2016. Performances of lactating yaks on silage 
and complete feed block based feeding regiments. Indian J Anim Sci, 86: 203-205

Munasik M, Anwar S and Prajitno CH, 2015. The various of complete feed block for dairy cattle. Anim Prod, 16(3): 183-188

Nagalakhsmi D and Reddy DN, 2011. On farm performance of lambs and buffaloes fed expander extruder processed cotton stalks based complete diets. Indian J Anim Nutr, 28(3): 253-258

Prasad CS, Gowda NKS and Ramana JV, 2001. Feeding strategies to enhance animal productivity. Proceedings of the Xth Animal Nutrition Conference, NDRI, Karnal, India, pp 23-45

Raghuvansi SKS, Prasad R, Misra AK, Mishra AS, Tripathi MK et al., 2002. Rumen degradation kinetics (in sacco) of Brassica Campestris (mustard) straw and Pennistum Typhoides (bajra) stover based tree containing complete feed blocks. In: Proc: Xth International Congress on Animal Production for Food and Environment Security, New Delhi, India on Sept 23-27, pp 233

Raghuvansi SKS, Prasad R, Tripathi MK, Mishra AS, Chaturvedi $\mathrm{OH}$ et al., 2007. Effect of complete feed blocks or grazing and supplementation of lambs on performance, nutrient utilisation, rumen fermentation and rumen microbial enzymes. Animal, 1(2): 221-226, doi: 10.1017/ S1751731107284058

Reddy GVN, Wilhelina PO and Reddy MS, 2003. Effect of differently processed complete diet on performance of murrah buffaloes. Indian J Anim Nutr, 20(2): 131-135

Saijpaul S, Chandrahas and Saini AL, 2016. Effect of concentrate feed and crop residue based complete feed block on nutrient utilization, growth and physiological performance of beetal kids under stall-fed conditions. Anim Nutr Feed Technol, 16(1): 71-81, doi: 10.5958/0974181X.2016.00007.X

Salem HB and Nefzaoui A, 2003. Feed blocks as alternative supplements for sheep and goats. Small Ruminant Res, 49(3): 275-288, doi: 10.1016/S0921-4488(03)00144-5

Samanta AK, Singh KK, Das MM, Maity SB and Kundu SS, 2003. Effect of complete feed block on nutrient utilisation and rumen fermentation in Barbari goats. Small Ruminant Res, 48(2): 95102, doi: 10.1016/S0921-4488(02)00262-6

Samanta AK, Singh KK and Das MM, 2008. Effect of complete feed block on dry matter intake and milk yield in crossbred cows. Indian Vet J, 85: 749-752

Sarker NR, Yeasmin D, Habib MA and Tabassum F, 2019. Feeding effect of total mixed ration on milk yield, nutrient intake, digestibility and rumen environment in red Chittagong cows. Asian J Med Biol Res, 5(1): 71-77, doi: 10.3329/ ajmbr.v5i1.41048

Sharma D, Tiwari DP and Mondal BC, 2010. Performance of crossbred female calves fed complete ration as mash or block vis-à-vis conventional ration. Indian J Anim Sci, 80(6): 556-560

Singh J, Lohan OP and Rathee CS, 1998. Evaluation of berseem based complete feed blocks in growing buffalo calves. Indian J Anim Sci, 68: 480-483

Singh KK, Das MM, Samanta AK and Kundu SS, 2007. Comparative growth performance of crossbred calves fed on completes diet in mash or block form. Indian J Anim Sci, 77: 1021-1025

Singh PK, Chandramoni C, Kumar K and Kumar S, 2016. Effect of feeding wheat and rice straw based complete feed blocks on nutrients utilization, blood biochemical and growth performance in crossbred calves. Indian J Anim Sci, 86(7): 771-776

Vaithiyanathan S, Raghuvansi SKS, Prasad R, Mishra AS, Misra AK et al., 2004. Effect of feeding different tree leaves and mustard (Brassica Campestris) straw based complete feed blocks on rumen microbial enzymes and microbial protein supply in sheep. In: Proc: National Seminar on Opportunities and Challenges in Nutrition and Feeding Management of Sheep, Goat and Rabbit For Sustainable Production, CSWRI, Avikanagar, Rajasthan, India, Feb 10-12, pp 350

Verma AK, Mehra UR, Dass RS and Singh A, 1996. Nutrient utilization by Murrah buffaloes (Bubalus Bubalis) from compressed complete feed blocks. Anim Feed Sci Technol, 59(4): 255263, doi: 10.1016/0377-8401(95)00911-6

Wanapat M, Petlum A and Pimpa O, 1999. Strategic supplementation with a high-quality feed block on roughage intake, milk yield and composition, and economic return in lactating dairy cows. Asian-Australas J Anim Sci, 12(6): 901903, doi: 10.5713/ajas.1999.901

Yadav KK, Rathee CS and Lohan OP, 1990. Effect of compaction of roughage based complete feed on digestibility and rumen parameters. Indian J Anim Nutr, 7(1): 27-30

Received - 12.04.2021, Accepted - 21.05.2021, Published-01.06.2021

Section Editor: Dr. A. K. Patra, Associate Editor 